\title{
Clinical importance of immunonutrition in infants: a review of the recent literature
}

\author{
Ji Sook Park, MD, PhD ${ }^{1,2}$ \\ ${ }^{1}$ Department of Pediatrics, Gyeongsang National University Hospital, Gyeongsang National University College of Medicine, Jinju, Korea; ${ }^{2}$ Institute of Health Sciences, \\ Gyeongsang National University, Jinju, Korea
}

During the last decades, the role of nutrition has been well elucidated in medicine, especially among critically ill infants and children. Many nutrients have the potential to modulate the immune system. A healthy immune system is essential for the prevention and recovery of many pediatric illnesses. Intervention using specific nutrients for the immune system is called immunonutrition. Immunonutrient supplementation has been attempted to modulate inflammatory or immune responses, leading to an improved clinical course of critically ill patients with prolonged nutritional supplementation parenterally or enterally. This review discusses immunomodulatory nutrients for infants based on the recent literature.

Key words: Immune system, Infant, Immunomodulation, Nutrient

\section{Key message}

Nutrients are important in the developing immune system. Human milk supplies diverse bioactives to prevent acute infection or chronic inflammation. Immunoglobulins, lactoferrin, and glutamine in human milk decrease gastrointestinal and respiratory infection. Human milk oligosaccharides promote the growth of intestinal microbiota, the gut barrier, and antimicrobial or antiviral activity. Micronutrients act as antiinflammatory immunonutrients, too. However, the toxicity of some nutrients from an overdose should be considered.

\section{Introduction}

Nutrition is essential in pediatric growth and development. It also plays a pivotal role in preventing and improving outcomes of diverse diseases in pediatric patients by maintaining an optimal immune response. ${ }^{1)}$ Nutrition and the immune system are closely correlated. Nutritional intervention that has a direct or indirect immunologic effect is called immunonutrition. ${ }^{2)}$ The concept of immunonutrition differs from that of folklore medicines or foods based on individual experiences and religious faiths that are not proven via the scientific process. ${ }^{3)}$

The immune system is immature at birth, but passive immunity transmitted from the mother through the placenta and the breastmilk can protect against infection in the neonatal period. ${ }^{4)}$ Negative nutritional alterations during the prenatal or neonatal period can lead to immunologic changes, increasing the risk of infection and chronic inflammatory disease. Early-life nutritional exposure is a significant determinant of immune health. ${ }^{5)}$ The present review aimed to discuss the immunological role of several nutrients for infants to prevent infectious diseases or noncommunicable diseases later in life based on the recent scientific literature.

\section{Human milk}

Human milk, the first food, delivers diverse nutritional and immunologic factors to neonates that contribute to development of the immune system. ${ }^{4}$ As an optimal and exclusive nutritional source, it is recommended for all infants from birth to 6 months of age. ${ }^{6}$ Human milk contains immunologic, protective, and trophic components such as immunoglobulins, immune-regulatory cytokines, microbiologic factors, and diverse cell types (Table 1).,3) The immunologic and diverse components of human milk support the immature immune system in neonates and feature many immunonutritive benefits for infants. ${ }^{8)}$ Breastfeeding, especially the duration of exclusive breastfeeding, is related with decreased gastrointestinal and respiratory infections in early life. ${ }^{9-}$

${ }^{11)}$ It can also promote optimal health outcomes in later life. ${ }^{12)}$

\section{Immunoglobulins}

Immunoglobulin (Ig) A, IgG, IgM, and IgE are found in human milk. The most abundant Ig is secretary IgA (sIgA), followed by secretary IgG. SIgA in human milk is not fully digested by gastric acid in preterm or term infants. It provides lower gastrointestinal immunity and prevents the binding of toxins, bacteria, and viruses to the intestinal mucosa by neutralizing them. ${ }^{13,14)} \mathrm{Al}$.

Corresponding author: Ji Sook Park, MD, PhD. Department of Pediatrics, Gyeongsang National University Hospital, Gyeongsang National University College of Medicine, 15 Jinju-daero 816beon-gil, Chiram-dong, Jinju 52727, Korea 


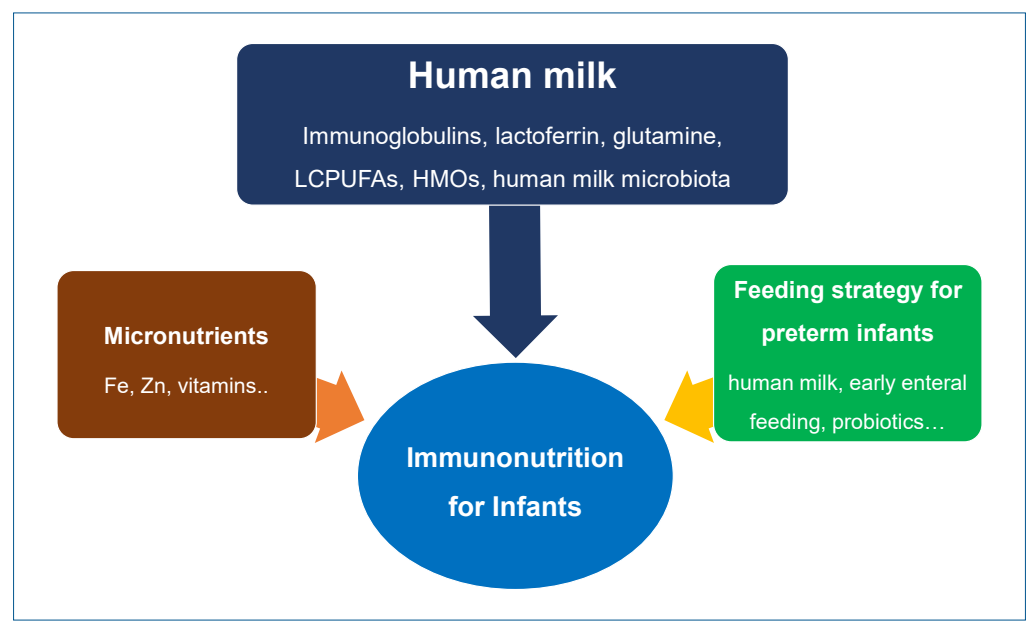

Graphical abstract

Table 1. Immunoprotective properties of human milk

\begin{tabular}{ll}
\hline Immunoprotective property & \multicolumn{1}{c}{ Components } \\
\hline Immunoglobulins & IgA, secretary IgA, IgG, IgM, IgE \\
Immuno-regulatory cytokines & IL6, IL8, TNFa, TGF $\beta 1$, TGF $\beta 2$ \\
Growth factors & EGF, TGFa, TGF $\beta$ \\
Microbiologic factors & $\begin{array}{c}\text { Human milk oligosaccharides, probiotic } \\
\text { bacteria, Latoferrin, Lysozyme }\end{array}$ \\
Others & $\begin{array}{c}\text { Medium- and Long-chain polyunsa- } \\
\text { turated free fatty acids }\end{array}$ \\
\hline
\end{tabular}

IL, interleukin; TNF, tumor necrosis factor; TGF, transforming growth factor; EGF, epidermal growth factor.

Adjusted from Gregory et al. ${ }^{7)}$ and Carr et al. ${ }^{12)}$

though sIgA in human milk decreases over time, its production in breastfed infants increases over the first 6 months of life. ${ }^{15,16)}$ $\operatorname{IgG}$ is the main immunoglobulin in the blood. It is also present in human milk, albeit at low levels. ${ }^{17)}$ However, IgG levels tend to increase in human milk as breastfeeding continues. Several studies suggest the possibility of IgG in human milk as a protective role in decreasing infections in breastfed infants. ${ }^{12,17,18)}$ Human milk can transfer IgM to infants. Term infants can partially digest IgM, whereas preterm infants cannot. ${ }^{13)}$ Human milk also contains allergen-specific IgG and IgE that may help sensitize infants. ${ }^{19)}$

\section{Lactoferrin}

Lactoferrin is a rich whey protein in human milk that binds well with iron. Lactoferrin in human milk is known to prevent bacterial, fungal, and viral infections. As iron is essential for microorganism growth, the iron-binding affinity of lactoferrin may inhibit bacterial growth by competing with bacteria to bind iron. However, the reported protective effects of recombinant or bovine lactoferrin are conflicting. ${ }^{20,21)}$

\section{Glutamine}

Glutamine, which is abundant in human milk, has been considered a fuel for rapidly dividing enterocytes and immune cells. It is a conditionally essential amino acid in critically ill patients, especially preterm in infants. ${ }^{20,22)} \mathrm{A}$ blinded randomized study reported that glutamine supplementation for 1 month can reduce the rate of sepsis in preterm infants by blunting HLA-DR ${ }^{+}$and CD16 ${ }^{+} \mathrm{T}$ lymphocytes. ${ }^{23)}$ Glutamine has been theoretically considered to prevent necrotizing enterocolitis (NEC), but recent well-designed randomized controlled trials have not proven the benefit of glutamine supplementation for reducing NEC rates. ${ }^{8)}$

\section{Long-chain polyunsaturated fatty acids}

Human milk contains a considerable amount of long-chain polyunsaturated fatty acids (LCPUFAs). Linoleic acid (18:2n-6) and alpha-linolenic acid (18:3n-3) are essential LCPUFAs that can modulate diverse immune responses in the body via lipoxins, prostaglandins, and thromboxanes. ${ }^{24)}$ LCPUFA supplementation can significantly reduce bronchopulmonary dysplasia and NEC in preterm infants by downregulating platelet-activating factor (PAF) and PAF receptor, and by downregulating endotoxin translocation into the systemic circulation. ${ }^{20,24)}$ It can also help develop retinal and cognitive function in infants. ${ }^{25,26)}$ The mean levels of arachidonic acid (AA) and docosahexaenoic acid (DHA) in human milk are about $0.5 \%$ and $0.3 \%$ of total fatty acids, respectively, but the ratio of AA/DHA in mature human milk is considerably variable depending on a mother's diet and region. ${ }^{27)}$ Both DHA and AA are included in infant formula at amounts at least equal to DHA in human milk. ${ }^{27)}$ However, the recommended dosages or ratios remain unclear.

\section{Human milk oligosaccharides}

Human milk oligosaccharides (HMOs) is the third most abundant substance in human milk, followed by lactose and lipids. The profiles of HMOs are quite diverse, with more than 200 distinct structures that differ from those of other mammals. ${ }^{28-30)}$ The secretor and Lewis genes determine HMO diversity. ${ }^{12)}$ HMOs are not digested by gastric acid and act as prebiotics by stimulating the growth of intestinal microbiota. ${ }^{12)}$ The interaction of HMOs occurs mainly in Bifidobacterium infantis, Bifidobacterium bifidum, Bacteroides fragilis, and Bacteroides vulgatus. ${ }^{3132)}$ Another commensal bacteria, Escherichia coli, benefits indirectly from $\mathrm{HMOs}$ using metabolites from $B$. fragilis 
when HMOs are degraded. ${ }^{33)}$ HMOs also provide antimicrobial activities by increasing the sensitivity of Group B Streptococcus, Staphylococcus aureus, or Acinetobacter baumannii to antibiotics. ${ }^{3435)}$ They also provide antiviral activity against rotavirus, norovirus, influenza, and human immunodeficiency virus by interacting with immune cells and inhibiting viral invasion. ${ }^{36,37)}$ In addition, as an anti-pathogen, 2'-fucosyllactose (FL) of HMOs acts as a soluble decoy receptor for Campylobacter jejuni and reduces colonization. ${ }^{38,39)}$ Lacto-N-fucopentaose I and 2'-FL reduce enteropathogenic $E$. coli adhesion and reduce pathoge. nicity by binding to heat-labile enterotoxin type $1 .{ }^{40)} \mathrm{HMOs}$ improve gut barrier function by promoting epithelial cell maturation via short-chain fatty acids, microbiota metabolites of HMOs, and glycocalyx alterations. ${ }^{12,41)}$ They can also enhance the local and systemic immune system by inhibiting Toll-like receptors and interacting with dendritic cells, leading to T-cell proliferation. ${ }^{12,42-44)} \mathrm{HMOs}$ as immunonutrients play a role in promoting healthy gut microbiota, protecting against bacterial and viral infections, improving gut barrier function, and optimizing immune function (Table 2). Therefore, HMOs play a potential role in preventing infection and allergic diseases (Table 3). ${ }^{45)}$

\section{Human milk microbiota}

The initial formation of neonatal intestinal microbiota depends on maternal microbiota via adherence to intestinal cells and suppression of inflammation by the interaction with dendritic cell and the induction of $\mathrm{T}$ regulatory cell production. ${ }^{46)}$ The maternal microbiota is affected by diverse conditions, such as the prenatal use of antibiotics, health status, body mass index, and

Table 2. Main effects of human milk oligosaccharides as immunonutrients

\begin{tabular}{|c|c|}
\hline Immune modulation & Effects of HMOs on infantile immunity \\
\hline \multirow[t]{2}{*}{ Shaping the gut microbiota } & $\begin{array}{l}\text { HMOs stimulate the growth of intestinal microbiota and shape gut microbiota compositions of Bacteroides spp., } \\
\text { Clostridium spp., and especially in Bifidobacterium spp. in early life. }{ }^{12,31,32)}\end{array}$ \\
\hline & $\begin{array}{l}\text { HMOs modulate the transcriptional activity of Bacteroides fragilis, rather than modifying their relative abundance. } \\
\text { Another commensal Escherichia coli benefits indirectly by metabolites of } B \text {. fragilis upon HMOs degradation. }\end{array}$ \\
\hline \multirow[t]{2}{*}{ Antimicrobial and antiviral activities } & $\begin{array}{l}\text { HMOs provide antimicrobial or antiviral activities by increasing sensitivity of pathogens, interacting immune cells } \\
\text { or inhibiting direct invasion. }{ }^{34-37)}\end{array}$ \\
\hline & $\begin{array}{l}\text { HMOs act as pathogen binding decoys to prevent Campylobacter jejuni or enteropathogenic E. coli, reducing } \\
\text { colonization and pathogenicity. }\end{array}$ \\
\hline Gut immunity & $\begin{array}{l}\text { HMOs reduce the intestinal permeability by influencing epithelial proliferation and modulating tight junction } \\
\text { protein expression via microbiota metabolites such as short-chain fatty acid, development of intestinal } \\
\text { glycocalyx, and microorganism-associated molecular patterns signaling. }{ }^{12,41,42,44,68)}\end{array}$ \\
\hline
\end{tabular}

Table 3. Recent studies of the prevention of infectious and noninfectious diseases using human milk oligosaccharides (HMOs)

\begin{tabular}{|c|c|c|c|}
\hline Source & Target & Study design & Results \\
\hline $\begin{array}{l}\text { Laucirica et al. } \\
2017^{68)}\end{array}$ & Rotavirus & $\begin{array}{l}\text { In vitro experimental study using MA104 cells } \\
\text { Comparison between experiment and control } \\
2^{\prime} \mathrm{FL}, 3^{\prime} \mathrm{SL}, 6^{\prime} \mathrm{SL} \text { and/or galacto-oligosaccharide were added } \\
\text { to MA104 cells infected with human rotavirus G1P[8] and } \\
\text { G2P[4] }\end{array}$ & $\begin{array}{l}\text { The maximum reduction of } \mathrm{G} 1 \mathrm{P}[8] \text { infectivity in } \\
2^{`} \mathrm{FL}(62 \% \text { reduction, } P<0.01) \\
\text { The maximum reduction of } \mathrm{G} 2 \mathrm{P}[4] \text { infectivity } \\
\text { with the mixture of } 3 \text { 'SL+6'SL }(73 \% \text { reduction, } \\
P<0.01)\end{array}$ \\
\hline $\begin{array}{l}\text { Leung et al. } \\
2020^{69)}\end{array}$ & $\begin{array}{l}\text { Upper respiratory tract } \\
\text { infection (URTI) and } \\
\text { Duration of gastrointe- } \\
\text { stinal tract infection } \\
\text { (GITI) }\end{array}$ & $\begin{array}{l}\text { Double-blinded, randomized controlled trial } \\
\text { Clinical trial of different young child formula: YCF-Ref, } \\
\text { standard milk formula; YCF-A, milk formula containing Igs, } \\
\text { lactoferrin, TGF- } \beta, 2^{\prime} F L \text {, and milk fat; YCF-B, milk formula } \\
\text { containing containing lower levels of the bioactive proteins } \\
\text { in YCF-A; YCF-C, milk formula containing } 2{ }^{`} \text { FL } \\
461 \text { Healthy Chinese children aged } 1-2.5 \text { years }\end{array}$ & $\begin{array}{l}\text { Safe in toddlers } \\
\text { No significant between-group differences on } \\
\text { URTI incidence and GITI duration }\end{array}$ \\
\hline $\begin{array}{l}\text { Autran et al. } \\
2018^{70)}\end{array}$ & $\begin{array}{l}\text { Necrotizing enterocoli- } \\
\text { tis (NEC) in preterm } \\
\text { infants }\end{array}$ & $\begin{array}{l}\text { Multicenter prospective clinical cohort study } \\
200 \text { Mother-VLBW infant pairs } \\
\text { Analyzed HMO composition in BM } \\
\text { NEC (Bell stage } 2 \text { or } 3 \text { ) }\end{array}$ & $\begin{array}{l}\text { Lower concentration of disialyllacto-N-tetraose } \\
\text { in BM in NEC cases }\end{array}$ \\
\hline $\begin{array}{l}\text { Lodge et al. } \\
2020^{71)}\end{array}$ & $\begin{array}{l}\text { Allergic disease (sen- } \\
\text { sitization, wheeze, } \\
\text { asthma, and eczema) }\end{array}$ & $\begin{array}{l}\text { Observational cohort study: the Melbourne Atopy Cohort } \\
\text { study (high-allergy-risk birth cohort) } \\
\text { Colostrum and early lactation milk from } 285 \text { mothers } \\
\text { Multiple follow-ups up to age } 18 \text { years in offsprings } \\
\text { Comparisons of HMOs contents in BM } \\
\text { Comparisons of allergic diseases in offsprings }\end{array}$ & $\begin{array}{l}\text { Exposure to acidic Lewis HMOs was associated } \\
\text { with a higher risk of allergic diseases and } \\
\text { asthma (OR asthma at } 18 \text { years, } 5.82 \text { ) } \\
\text { Exposure to the acidic predominant profile was } \\
\text { associated with a reduced risk of food } \\
\text { sensitization (OR at } 12 \text { years, } 0.08)\end{array}$ \\
\hline $\begin{array}{l}\text { Li et al. } \\
\text { 2021 }\end{array}$ & Food allergy & $\begin{array}{l}\text { In vivo and in vitro experimental study using allergic mouse } \\
\text { model } \\
\text { Oral administration of } 2^{`} \mathrm{FL} \text { or HMO }\end{array}$ & $\begin{array}{l}2^{`} \mathrm{FL} \text { dose-dependently inhibited the TLR4/NF- } \\
\text { kB inflammatory pathway and upregulated } \\
\text { miR-146a expression } \\
2^{`} \mathrm{FL} \text { reduced } \beta \text {-lactoglobulin allergy via } \\
\text { regulation of miR-146a }\end{array}$ \\
\hline
\end{tabular}

2'FL, 2'-fucosyllactose; 3'SL, 3'-sialyllactose; 6'SL, 6'-sialyllactose; MA104 cells, African green monkey kidney epithelial cells; TGF, transforming growth factor; YCF, young child formula; BM, breast milk; OR, odds ratio; TLR4, toll-like receptor 4; VLBW, very low birth weight; NF-kB, nuclear factor kappa B; miR146a, microRNA 146a. 
gestational age. ${ }^{47)}$ The complex human milk microbiota changes over time and varies among mothers. However, they generally include Bifidobacterium and Lactobacillus spp, Streptococcus, Staphylococcus, Bacteroides, and Enterobacter. ${ }^{46,47)}$ The human milk microbiota can contribute to establishing healthy intestinal bacteria in neonates and infants. Lactobacillus in the human milk induces Th1 cytokines and natural killer cells. They can adhere to intestinal cells, leading to the increased colonization of beneficial bacteria and the inhibition of pathogenic adhesion in the gut. ${ }^{48,49)}$ Bifidobacterium may suppress interleukin-8 in the presence of pathogenic Salmonella ${ }^{50)}$ and Bacteroides may suppress inflammation in the laminar propria by increasing FOXP3 $\mathrm{T}$ cells using surface polysaccharide A. ${ }^{51)}$ Although human milk contains diverse beneficial microbiota, intestinal microbiota compositions differ between infants fed expressed human milk and those directly breastfed. The intestinal microbiota of expressed breastmilk-fed infants show higher amounts of potential pathogens such as Enterobacteriaceae but lower amounts of Bifidobacterium. ${ }^{47,52)}$ Human milk plays crucial roles in preventing infections and influencing long-term health like obesity or allergic diseases via diverse immune mechanisms. ${ }^{45)}$ However, further research is required regarding the combined effect of bioactive supplementation in formula.

\section{Micronutrients}

\section{Iron}

Infants and children with iron deficiency can be susceptible to infections due to impaired T-cell function which is associated with decreased production of interleukin 2.53) Iron supplementation can reverse the T-cell dysfunction.

\section{Zinc}

$\mathrm{Zn}$, the second most abundant metal in the human body following Fe, is a cofactor involved in DNA synthesis and repair. It is fundamental in protein synthesis as well as cell growth and differentiation. $\mathrm{Zn}$ deficiency occurs in acrodermatitis enteropathica, chronic malabsorption such as short bowel syndrome, or long-term insufficient supplementation of total parenteral nutrition. ${ }^{3)}$ Inadequate $\mathrm{Zn}$ intake increases diarrhea and pneumonia, especially in children younger than 5 years of age, and $\mathrm{Zn}$ supplementation can reduce the duration of diarrhea and respiratory illnesses. ${ }^{54)} \mathrm{Zn}$ acts as a signaling molecule in the immune system. ${ }^{55)} \mathrm{Zn}$ deficiency induces lymphopenia caused by decreased $\mathrm{B}$ cell differentiation in the bone marrow and interferon- $\gamma$ production. ${ }^{56,57)}$

\section{Vitamins}

Vitamins act as antioxidants by suppressing reactive oxygen radicals and activating antioxidant enzymes. ${ }^{58)}$ Antioxidants can play important roles in the immune response via phagocytic function, cytokine and immunoglobulin production, and cell- mediated responses. ${ }^{3)}$ Oxidative stress or free radicals are involved in the development of diverse illnesses including chronic inflammatory diseases, aging, and cancers. Vitamin E is a membrane-bound antioxidant that can act as a free radical scavenger that prevents damage from lipid peroxidation. When vitamin $\mathrm{E}$ deficiency is caused by chronic cholestasis or a chronic malabsorptive state, decreased activities of antioxidative enzymes and increased hepatic lipid peroxidation can occur. Vitamin C, a hydrophilic antioxidant that cannot be synthesized by the human body, acts as a cofactor in collagen synthesis by activating hydroxylase by reducing $\mathrm{Fe}^{3+}$ to $\mathrm{Fe}^{2+}$. It is involved in inhibition of the redox potential under oxygen radical reactions in the body. ${ }^{59)}$ Excess free radial generation and oxidant cellular damage have been postulated in the pathogenesis of NEC in preterm infants and inflammatory bowel disease in children and adults. Although further clinical studies are necessary, vitamins can be used as antioxidant and immunologic nutrients. ${ }^{60,61)}$

\section{Immunonutrition for preterm infants}

Preterm infants are vulnerable nutritionally and immunologically because they are more susceptible to unstable clinical conditions than term infants. Therefore, immunonutrition is more important for preterm than term infants. Immunonutritional clinical strategies can focus on preventing inflammatory or infectious issues that might be encountered in a neonatal intensive care unit. These strategies include feeding human milk (due to its diverse immunologic bioactive substances), providing early introduction and fast advancement of enteral feeding, and minimizing iatrogenic harm. ${ }^{7,62,63)}$ Although further research is needed to determine the appropriate strain, effective dosage, clinical approval, and quality and safety issues, the probiotics, prebiotics, or synbiotics supplementation to prevent NEC or sepsis can be an immunonutritional strategy for premature infants. ${ }^{64,65)}$

\section{Immunonutrition during the coronavirus disease 2019 pandemic}

During the coronavirus disease 2019 (COVID-19) pandemic, the whole world is struggling to find treatment regimens and effective vaccines based on immunologic knowledge. Immunonutrition is emerged as an adjuvant dietary supplementation technique. Although severe acute respiratory syndrome coronavirus 2 is thought to be transmitted mainly via the respiratory route, gastrointestinal symptoms are often manifested at first in infants, suggesting that it can invade enterocytes. ${ }^{66)}$ Early human milk feeding can promote an intestinal environment of tight enterocyte junctions by diverse bioactive substances and can contribute to reinforcing innate defense in neonates and infants. Therefore, early breastfeeding may provide prevention during the viral pandemic. ${ }^{67)}$ Clinical trials using a combination of dietary supplements such as vitamin C, vitamin 
$\mathrm{D}$, probiotics, and $\mathrm{Zn}$ are currently in progress. ${ }^{55)}$ The clinical and theoretical effects of nutrients on the immune system based on immunonutrition during this pandemic are very attractive. However, clinical and preclinical data are quite limited, and more well-designed studies are necessary.

\section{Conclusion}

Human milk is a major source of immunonutrients for healthy and sick babies. Bioactive substances in human milk can support neonatal and infantile immune systems directly and indirectly. HMOs are likely to have prebiotic effects that can enhance the colonization of beneficial intestinal bacteria. However, adding HMOs to standard or preterm formula requires more detailed future studies. Many micronutrients and vitamins may be supplemented as anti-inflammatory immunonutrients for infants. However, the toxicity of some nutrients from an overdose should be considered. Extensive studies of the effects of immunonutrients in the developing immune system have been performed (Tables 2, 3). Moreover, during this viral pandemic, the scientific interest in immunonutrition is increasing and further research is warranted to determine its clinical applications.

\section{Footnotes}

Conflicts of interest: No potential conflict of interest relevant to this article was reported.

Funding: This study received no specific grant from any funding agency in the public, commercial, or not-for-profit sectors.

ORCID:

Ji Sook Park @ https://orcid.org/0000-0002-4704-2246

\section{References}

1. Perez-Cano JF, Yaqoob P, Martin R, Escuer CM, Juarez-Rubio C. Immunonutrition in early life: diet and immune development. Clin Devel Immunol 2012;2012:207509.

2. Venter C, O'Mahony L. Immunonutrition: the importance of a new European Academy of Allergy and Clinical Immunology Working Group addressing a significant burden and unmet need. Allergy 2021;76:23035 .

3. Levy J. Immunonutrition: the pediatric experience. Nutrition 1998;14: 641-7.

4. Pai AU, Chandrasekhar P, Carvalho SR, Kumar S. The role of nutrition in immunity in infants and toddlers: An expert panel opinion. Clin Epidemiol Global Health 2018;6:155-9.

5. Palmer AC. Nutritionally mediated programming of the developing immune system. Adv Nutr 2011;2:377-95.

6. Section on Breastfeeding. Breastfeeding and the use of human milk. Pediatrics 2012;129:e827-41.

7. Gregory KE, Walker WA. Immunologic factors in human milk and disease prevention in the preterm infant. Curr Pediatr Rep 2013;1:10.1007/ s40124-013-0028-2.

8. Walsh V, McGuire W. Immunonutrition for preterm infants. Neonatology 2019;115:398-405.

9. Frank NM, Lynch KF, Uusitalo U, Yang J, Lonnrot M, Virtanen SM, et al. The relationship between breastfeeding and reported respiratory and gastrointestinal infection rates in young children. BMC Pediatr 2019; 19:339-019-1693-2.

10. Christensen N, Bruun S, Sondergaard J, Christesen HT, Fisker N, Zachariassen G, et al. Breastfeeding and infections in early childhood: a cohort study. Pediatrics 2020;146:e20191892.

11. Jang MJ, Kim YJ, Hong S, Na J, Hwang JH, Shin SM, et al. Positive association of breastfeeding on respiratory syncytial virus infection in hospitalized infants: a multicenter retrospective study. Clin Exp Pediatr 2020;63:135-40.

12. Carr LE, Virmani MD, Rosa F, Munblit D, Matazel KS, Elolimy AA, et al. Role of human milk bioactives on infants' gut and immune health. Front Immunol 2021;12:604080.

13. Demers-Mathieu V, Underwood MA, Beverly RL, Nielsen SD, Dallas DC. Comparison of human milk immunoglobulin survival during gastric digestion between preterm and term infants. Nutrients 2018;10:631.

14. Mantis NJ, Farrant SA, Mehta S. Oligosaccharide side chains on human secretory IgA serve as receptors for ricin. J Immunol 2004;172:6838-45.

15. Perkkio M, Savilahti E. Time of appearance of immunoglobulin-containing cells in the mucosa of the neonatal intestine. Pediatr Res 1980;14:9535.

16. Kohler H, Donarski S, Stocks B, Parret A, Edwards C, Schroten H. Antibacterial characteristics in the feces of breast-fed and formula-fed infants during the first year of life. J Pediatr Gastroenterol Nutr 2002;34: 188-93.

17. Abuidhail J, Al-Shudiefat AA, Darwish M. Alterations of immunoglobulin $\mathrm{G}$ and immunoglobulin $\mathrm{M}$ levels in the breast milk of mothers with exclusive breastfeeding compared to mothers with non-exclusive breastfeeding during 6 months postpartum: the Jordanian cohort study. Am J Hum Biol 2019;31:e23197.

18. Kazimbaya KM, Chisenga CC, Simuyandi M, Phiri CM, Laban NM, Bosomprah S, et al. In-vitro inhibitory effect of maternal breastmilk components on rotavirus vaccine replication and association with infant seroconversion to live oral rotavirus vaccine. PLoS One 2020;15: e0240714.

19. Hochwallner H, Alm J, Lupinek C, Johansson C, Mie A, Scheynius A, et al. Transmission of allergen-specific IgG and IgE from maternal blood into breast milk visualized with microarray technology. J Allergy Clin Immunol 2014;135:1213-5.

20. Huang Y, Liboni K, Neu J. Immunonutrients and the critically ill neonate. NeoReviews 2003;4:e20.

21. ELFIN trial investigators group. Enteral lactoferrin supplementation for very preterm infants: a randomised placebo-controlled trial. Lancet 2019;393:423-33.

22. Becker RM, Wu G, Galanko JA, Chen W, Maynor AR, Bose CL, et al. Reduced serum amino acid concentrations in infants with necrotizing enterocolitis. J Pediatr 2000;137:785-93.

23. Neu J, Roig JC, Meetze WH, Veerman M, Carter C, Millsaps M, et al. Enteral glutamine supplementation for very low birth weight infants decreases morbidity. J Pediatr 1997;131:691-9.

24. Lapillonne A, Moltu SJ. Long-chain polyunsaturated fatty acids and clinical outcomes of preterm infants. Ann Nutr Metab 2016;69:35-44.

25. Alshweki A, Munuzuri AP, Bana AM, de Castro MJ, Andrade F, AldamizEchevarria L, et al. Effects of different arachidonic acid supplementation on psychomotor development in very preterm infants; a randomized controlled trial. Nutr J 2015;14(101). https://doi.org/10.1186/s12937015-0091-3.

26. Colombo J, Carlson SE, Cheatham CL, Shaddy DJ, Kerling EH, Thodosoff JM, et al. Long-term effects of LCPUFA supplementation on childhood cognitive outcomes. Am J Clin Nutr 2013;98:403-12.

27. Salem N Jr, Van Dael P. Arachidonic acid in human milk. Nutrients 2020;12:626. 
28. Kunz C, Rudloff S, Baier W, Klein N, Strobel S. Oligosaccharides in human milk: structural, functional, and metabolic aspects. Annu Rev Nutr 2000;20:699-722.

29. Erney RM, Malone WT, Skelding MB, Marcon AA, Kleman-Leyer KM, O'Ryan ML, et al. Variablility of human milk neutral oligosaccharides in a diverse population. J Pediatr Gastroenterol Nutr 2000;30:181-92.

30. Albrecht S, Lane JA, Marino K, Al Busadah KA, Carrington SD, Hickey RM, et al. A comparative study of free oligosaccharides in the milk of domestic animals. Br J Nutr 2014;111:1313-28.

31. Marcobal A, Barboza M, Froehlich JW, Block D, German JB, Lebrilla $\mathrm{CB}$, et al. Consumption of human milk oligosaccharides by gut-related microbes. J Agric Food Chem 2010;58:5334-40.

32. Tamburini S, Shen N, Wu HC, Clemente JC. The microbiome in early life: implications for health outcomes. Nat Med 2016;22:713-22.

33. Charbonneau MR, O'Donnell D, Blanton LV, Totten SM, Davis JC, Barratt MJ, et al. Sialylated milk oligosaccharides promote microbiotadependent growth in models of infant undernutrition. Cell 2016;164: 859-71.

34. Ackerman DL, Craft KM, Doster RS, Weitkamp J, Aronoff DM, Gaddy JA, et al. Antimicrobial and antibiofilm activity of human milk oligosaccharides against Streptococcus agalactiae, Staphylococcus aureus, and Acinetobacter baumannii. ACS Infect Dis 2018;4:315-24.

35. Craft KM, Gaddy JA, Townsend SD. Human milk oligosaccharides (HMOs) sensitize group B streptococcus to clindamycin, erythromycin, gentamicin, and minocycline on a strain specific basis. ACS Chem Biol 2018;13:2020-6.

36. Morrow AL, Ruiz-Palacios GM, Altaye M, Jiang X, Guerrero ML, Meinzen-Derr JK, et al. Human milk oligosaccharides are associated with protection against diarrhea in breast-fed infants. J Pediatr 2004;145:297303.

37. Koromyslova A, Tripathi S, Morozov V, Schroten H, Hansman GS. Human norovirus inhibition by a human milk oligosaccharide. Virology 2017;508:81-9.

38. Zhang S, Li T, Xie J, Zhang D, Pi C, Zhou L, et al. Gold standard for nutrition: a review of human milk oligosaccharide and its effects on infant gut microbiota. Microb Cell Fact 2021;20:108.

39. YuZT, Nanthakumar NN, Newburg DS. The human milk oligosaccharide 2'-fucosyllactose quenches campylobacter jejuni-induced inflammation in human epithelial cells HEp-2 and HT-29 and in mouse intestinal mucosa. J Nutr 2016;146:1980-90.

40. El-Hawiet A, Kitova EN, Klassen JS. Recognition of human milk oligosaccharides by bacterial exotoxins. Glycobiology 2015;25:845-54.

41. Kong C, Elderman M, Cheng L, de Haan BJ, Nauta A, de Vos P. Modulation of intestinal epithelial glycocalyx development by human milk oligosaccharides and non-digestible carbohydrates. Mol Nutr Food Res 2019;63:e1900303.

42. Wang C, Zhang M, Guo H, Yan J, Liu F, Chen J, et al. Human milk oligosaccharides protect against necrotizing enterocolitis by inhibiting intestinal damage via increasing the proliferation of crypt cells. Mol Nutr Food Res 2019;63:e1900262.

43. Xiao L, van De Worp WR, Stassen R, van Maastrigt C, Kettelarij N, Stahl $\mathrm{B}$, et al. Human milk oligosaccharides promote immune tolerance via direct interactions with human dendritic cells. Eur J Immunol 2019;49: 1001-14.

44. Sodhi CP, Wipf P, Yamaguchi Y, Fulton WB, Kovler M, Nino DF, et al. The human milk oligosaccharides 2'-fucosyllactose and 6'-sialyllactose protect against the development of necrotizing enterocolitis by inhibiting toll-like receptor 4 signaling. Pediatr Res 2021;89:91-101.

45. Yeruva L, Munblit D, Collado MC. Editorial: Impact of early life nutrition on immune system development and related health outcomes in later life. Front Immunol 2021;12:668569.

46. Pannaraj PS, Li F, Cerini C, Bender JM, Yang S, Rollie A, et al. Association between breast milk bacterial communities and establishment and development of the infant gut microbiome. JAMA Pediatr 2017;171:64754.

47. Moossavi S, Sepehri S, Robertson B, Bode L, Goruk S, Field CJ, et al. Composition and variation of the human milk microbiota are influenced by maternal and early-life factors. Cell Host Microbe 2019;25:324-35.

48. M'Rabet L, Vos AP, Boehm G, Garssen J. Breast-feeding and its role in early development of the immune system in infants: consequences for health later in life. J Nutr 2005;138:1782S-1790S.

49. Damaceno QS, Souza JP, Nicoli JR, Paula RL, Assis GB, Figueiredo HC, et al. Evaluation of potential probiotics isolated from human milk and colostrum. Probiotics Antimicrob Proteins 2017;9:371-9.

50. Malago J, Tooten P, Koninkx J. Anti-inflammatory properties of probiotic bacteria on salmonella-induced IL-8 synthesis in enterocyte-like caco-2 cells. Benef Microbes 2010;1:121-30.

51. Round JL, Mazmanian SK. Inducible Foxp3 + regulatory T-cell development by a commensal bacterium of the intestinal microbiota. Proc Natl Acad Sci US A 2010;107:12204-9.

52. Fehr K, Moossavi S, Sbihi H, Boutin R, Bode L, Robertson B, et al. Breastmilk feeding practices are associated with the co-occurrence of bacteria in mothers' milk and the infant gut: the CHILD cohort study. Cell Host Microbe 2020;28:285-97.

53. Thibault H, Galan P, Selz F, Preziosi P, Olivier C, Badoual J, et al. The immune response in iron-deficient young children: Effect of iron supplementation on cell-mediated immunity. Eur J Pediatr 1993;152: $120-4$.

54. Lassi ZS, Kurji J, Oliveira CS, Moin A, Bhutta ZA. Zinc supplementation for the promotion of growth and prevention of infections in infants less than six months of age. Cochrane Database Syst Rev 2020;4:CD010205.

55. Pal A, Squitti R, Picozza M, Pawar A, Rongioletti M, Dutta AK, et al. Zinc and COVID-19: basis of current clinical trials. Biol Trace Elem Res 2021;199:2882-92.

56. Fukada T, Hojyo S, Hara T, Takagishi T. Revisiting the old and learning the new of zinc in immunity. Nat Immunol 2019;20:248-50.

57. Beck FW, Prasad AS, Kaplan J, Fitzgerald JT, Brewer GJ. Changes in cytokine production and $\mathrm{T}$ cell subpopulations in experimentally induced zinc-deficient humans. Am J Physiol 1997;272:E1002-7.

58. Youn H. Antioxidant nutrition in children. Korean J Pediatr 2004;9:S55976.

59. Youn $\mathrm{H}$. New nutritional concepts of vitamins and minerals. Korean J Pediatr 2005;48:1295-309.

60. Yamada T, Grisham MB. Role of neutrophil-derived oxidants in the pathogenesis of intestinal inflammation. Klin Wochenschr 1991;69:98894.

61. Kruidenier L, Kuiper I, Lamers CB, Verspaget HW. Intestinal oxidative damage in inflammatory bowel disease: semi-quantification, localization, and association with mucosal antioxidants. J Pathol 2003;201:28-36.

62. SIFT Investigators Group. Early enteral feeding strategies for very preterm infants: current evidence from Cochrane reviews. Arch Dis Child Fetal Neonatal Ed 2013;98:F470-2.

63. Dorling J, Hewer O, Hurd M, Bari V, Bosiak B, Bowler U, et al. Two speeds of increasing milk feeds for very preterm or very low-birthweight infants: the SIFT RCT. Health Technol Assess 2020;24:1-94.

64. Chi C, Buys N, Li C, Sun J, Yin C. Effects of prebiotics on sepsis, necrotizing enterocolitis, mortality, feeding intolerance, time to full enteral feeding, length of hospital stay, and stool frequency in preterm infants: a meta-analysis. Eur J Clin Nutr 2019;73:657-70.

65. Johnson-Henry KC, Abrahamsson TR, Wu RY, Sherman PM. Probiotics, prebiotics, and synbiotics for the prevention of necrotizing enterocolitis. Adv Nutr 2016;7:928-37.

66. Zhou MY, Xie XL, Peng YG, Wu MJ, Deng XZ, Wu Y, et al. From SARS to COVID-19: what we have learned about children infected with COVID-19. Int J Infect Dis 2020;96:710-4.

67. Peroni DG, Fanos V. Lactoferrin is an important factor when breastfeeding and COVID-19 are considered. Acta Paediatr 2020;109:2139-40.

68. Laucirica DR, Triantis V, Schoemaker R, Estes MK, Ramani S. Milk oligosaccharides inhibit human rotavirus infectivity in MA104 cells. J Nutr 2017;147:1709-14.

69. Leung TF, Ulfman LH, Chong MKC, Hon KL, Khouw IMSL, Chan PKS, et al. A randomized controlled trial of different young child formulas on upper respiratory and gastrointestinal tract infections in Chinese toddlers. Pediatr Allergy Immunol 2020;31:745-54. 
70. Autran CA, Kellman BP, Kim JH, Asztalos E, Blood AB, Spence ECH, et al. Human milk oligosaccharide composition predicts risk of necrotizing enterocolitis in preterm infants. Gut 2018;67:1064-70.

71. Lodge CJ, Lowe AJ, Milanzi E, Bowatte G, Abramson MJ, Tsimiklis H et al. Human milk oligosaccharide profiles and allergic disease up to 18 years. J Allergy Clin Immunol 2021;147:1041-8.

72. Li A, Li Y, Zhang X, Zhang C, Li T, Zhang J, et al. The human milk oligosaccharide 2'-fucosyllactose attenuates beta-lactoglobulin-induced food allergy through the miR-146a-mediated Toll-like receptor 4/nuclear factor-kappa B signaling pathway. J Dairy Sci 2021;104:10473-84

How to cite this article: Park JS. Clinical importance of immunonutrition in infants: a review of the recent literature. Clin Exp Pediatr 2022;65:337-423. https://doi.org/10.3345/ cep.2021. 00570 